\title{
AJARAN, PENGAMALAN, DAN MAQAMAT TASAWUF
}

\author{
Oleh: Iqbal Firdaus \\ Iqbal.firdaus13@mhs.uinjkt.ac.id
}

\begin{abstract}
Abstrak: Salah satu ilmu yang bertujuan untuk menggapai kebahagiaan akhirat adalah Tasawuf. Tasawuf dalam dunia Islam baru akhir-akhir ini dipelajari sebagai ilmu, sebelumnya dipelajari sebagai jalan untuk mendekatkan diri kepada Tuhan. Manusia pada dasarnya adalah suci, maka kegiatan yang dilakukan oleh sebagian manusia untuk mensucikan diri merupakan naluri manusia. Usaha yang mengarah kepada pensucian jiwa terdapat di dalam kehidupan tasawuf. Tasawuf merupakan suatu ajaran untuk mendekatkan diri sedekat mungkin dengan Allah bahkan kalau bisa menyatu dengan Allah melalui jalan dan cara, yaitu maqâmât dan ahwâl.
\end{abstract}

Kata Kunci: Tasawuf, Ajaran, Pengamalan, Maqamat

\section{A. Pendahuluan}

Al-Qur`an dan hadis bukanlah sebuah aturan-aturan kaku yang membatasi ruang gerak manusia. Al-Qur`an dan hadis adalah panduan hidup yang menggiring manusia menuju ketentraman, kedamaian dan kebahagiaan. Kebahagiaan yang sempurna adalah kebahagiaan yang meliputi dua dimensi, yaitu dimensi dunia dan dimensi akhirat. Kebahagiaan di dunia dapat dirasakan dengan jiwa yang tentram. Kebahagiaan akhirat adalah kebahagiaan bertemu dan berkomunikasi dengan Sang Maha Pemilik Ruh, Allah SWT.

Salah satu ilmu yang bertujuan untuk menggapai kebahagiaan akhirat adalah Tasawuf. Tasawuf dalam dunia Islam baru akhir-akhir ini dipelajari sebagai ilmu, sebelumnya dipelajari sebagai jalan untuk mendekatkan diri kepada Tuhan. Manusia pada dasarnya adalah suci, maka kegiatan yang dilakukan oleh sebagian manusia untuk mensucikan diri merupakan naluri manusia. Usaha yang mengarah kepada pensucian jiwa terdapat di dalam kehidupan tasawuf. Tasawuf merupakan suatu ajaran untuk mendekatkan diri sedekat mungkin dengan Allah bahkan kalau bisa menyatu dengan Allah melalui jalan dan cara, yaitu maqâmât dan ahwâl. Untuk lebih jelasnya, dalam makalah ini saya akan mencoba memaparkan beberapa persoalan yang berhubungan dengan tasawuf, yaitu pengertian tasawuf, asal tasawuf Islam dan sumbernya, sejarah perkembangan tasawuf, ajaran dan pengamalan tasawuf, dan maqamat dalam tasawuf. 


\section{B. Asal Kata Tasawuf}

Mistisme dalam Islam diberi nama tasawuf dan oleh kaum orientalis Barat disebut sufisme. Kata sufisme dalam istilah orientalis barat khusus digunakan untuk mistisme Islam. Sufisme tidak dipakai untuk mistisme yang terdapat dalam agama-agama lain.

Teori mengenai asal usul dari kata tasawuf banyak ditemukan perbedaan pendapat di antara para cendekiawan. ${ }^{1}$ Sedangkan pandangan yang lain mengatakan bahwa kata tasawuf ditinjau dari etimologi berasal dari salah satu di antara teori-teori berikut:

1. Ahl al-ṣuffah (أهل الصفّة) yakni sahabat yang ikut hijrah bersama Nabi dari Mekkah ke Madinah dengan meninggalkan segala hartanya. Sehingga mereka hidup dalam keadaan miskin. Mereka tinggal di Masjid Nabi dan tidur dengan menjadikan pelana (suffah) mereka sebagai bantal. Sikap mereka yang begitu mulia walaupun dalam keadaan miskin serta tidak mementingkan duniawi sesuai dengan sifat-sifat yang dimiliki oleh seorang sufi.

2. Sesuai dengan صف (saff) pertama yang mana akan mendapatkan pahala dan kemuliaan dari Allah, demikian pula kaum sufi. Pendapat lain mengatakan bahwa teori ini didasarkan pada dua fenomena kehidupan para sufi. Yakni Pertama, berdasarkan kebiasaan para sufi yang datang lebih dahulu dan memilih barisan pertama ketika shalat berjamaah di masjid. Kedua, keberhasilan mereka dalam membangun persaudaraan kuat di antara mereka.

3. Berasal dari kata صفى dan صافى yakni suci. Sebagaimana seorang sufi yang menyucikan dirinya melalui latihan berat dan lama. Bahkan kesucian jiwa itu sendiri merupakan salah satu tujuan bertasawuf.

4. Dari bahasa Yunani, theosofi yakni theo berarti 'Tuhan' dan shopos bermakna 'hikmah's. Jadi theosofi adalah kearifan Tuhan atau bisa dikatakan manusia yang merindukan kearifan Tuhan. ${ }^{4}$

5. Berasal dari kata șūf (صوف) yang bemakna bulu domba atau wol kasar. Kain wol mengandung dua simbol yaitu lambang kefakiran dan lambang kerendahan hati dan kesederhanaan. 
6. Berasal dari kata șafwah yang berarti pilihan. Bagi para pengamat, para sufi diyakini sebagai kelompok orangorang yang terpilih di antara hamba Allah SWT. karena kesucian jiwa dan kedekatan mereka dengan Allah. ${ }^{6}$

7. Berasal dari kata sifah. Dikarenakan para sufi menghiasi diri mereka dengan kebaikan dan meninggalkan sifat-sifat tercela. $^{7}$

Menurut Abu Al-Wafa al-Taftazani dalam kitabnya Madkhal ila al-Tasawwuf al-Islami, di antara beberapa pendapat tersebut pendapat yang mengatakan berasal dari pakaian yang berasal dari bulu domba lah yang paling benar. ${ }^{8}$

Dalam al-Quran, tidak ditemukan kata sufi atau tasawuf secara implisit. Hanya saja, terdapat satu kata yang memiliki akar kata yang sama dengan kata sufi yakni أصو اف yang merupakan jamak dari lafaz صوف.Qur'an hanya terdapat -Dan kata tersebut dalam al ${ }^{9}$ dalam QS. An-Nahl [16]: $80^{10}$ yang berbunyi;

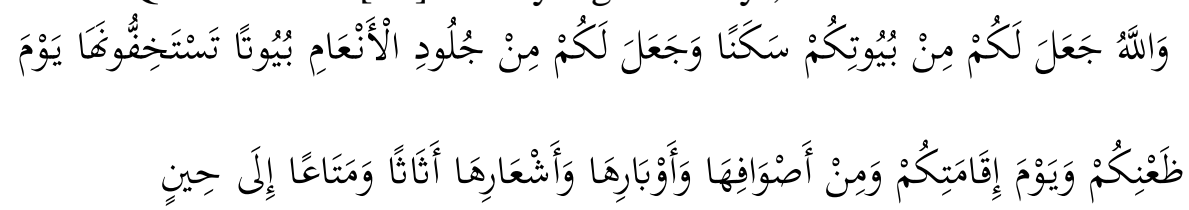

"Dan Allah menjadikan bagimu rumah-rumahmu sebagai tempat tinggal dan Dia menjadikan bagi kamu rumah-rumah (kemah-kemah) dari kulit binatang ternak yang kamu merasa ringan (membawa)nya di waktu kamu berjalan dan waktu kamu bermukim dan (dijadikan-Nya pula) dari bulu domba, bulu onta dan bulu kambing, alat-alat rumah tangga dan perhiasan (yang kamu pakai) sampai waktu (tertentu)."

Dalam ayat tersebut, menurut para mufassir dan ahli bahasa lafaz dikhususkan untuk bulu domba. ${ }^{11}$ Makna tersebut selaras dengan makna yang disepakati oleh Al-Taftazani sebagai asal kata tasawuf.

Sedangkan tasawuf ditinjau dari segi terminologi terdapat banyak pengertian yang disampaikan oleh ulama. Abu al-Hasan AsySyadzili $(1258 \mathrm{M})$ mengartikan bahwa tasawuf adalah segala praktik amalan dan latihan dalam diri seseorang melalui ibadah dan penyembahan lain guna mengembalikan diri kepada Allah swt. Sedangkan Ahmad Zarruq (1494 M) mendefinisikannya dengan pengetahuan yang dapat menata dan meluruskan hati serta membuatnya istimewa bagi Allah, mempergunakan pengetahuan 
tentang Islam, yang kemudian mengaitkannya guna meningkatkan kualitas perbuatan, serta memelihara diri dalam batasan-batasan hukum Islam dengan harapan muncul kearifan pada dirinya. ${ }^{12}$

Ma'ruf al-Karkhi juga memberikan definisi tentang tasawuf dengan singkat yakni mengambil hakikat dan meninggalkan yang ada di tangan makhluk. Muhammad Amin Kurdi mendefinisikan tasawuf dengan suatu yang dengannya diketahui hal ihwal kebaikan dan keburukan jiwa, cara membersihkannya dari yang tercela dan mengisinya dengan sifat-sifat terpuji, cara melaksanakan suluk dan perjalanan menuju keridhaan Allah dan meninggalkan laranganNya. ${ }^{13}$

Pada hakikatnya tasawuf itu mengandung dua prinsip, sebagaimana disampaikan oleh 'Abd ar-Rahman Badawi dalam kitabnya Tarikh at-Tashawwuf al-Islami, yakni pengalaman batin dalam hubungan langsung antara hamba dengan Tuhan dan "kesatuan" Tuhan dengan hamba. ${ }^{14}$ Sedangkan menurut Asep Usman Ismail, inti dari tasawuf adalah kesucian jiwa untuk menghadap Allah dan upaya mendekatkan diri secara individu kepada-Nya. ${ }^{15}$

\section{Asal Tasawuf Islam dan Sumbernya}

Terdapat dua teori yang mengatakan asal usul dari tasawuf, yakni teori yang berasal dari Islam sendiri dan juga teori yang berasal dari luar Islam. Orientalis Barat mengatakan bahwa tasawuf bukan murni dari ajaran Islam, sementara tokoh sufi mengatakan bahwa tasawuf merupakan inti ajaran Islam. ${ }^{16}$

Harun Nasution menyebutkan beberapa teori yang berasal dari luar Islam, yakni ${ }^{17}$ :

1. Pengaruh Kristen dengan paham menjauhi dunia dan hidup mengasingkan diri dalam biara-biara. Dalam literatur Arab memang terdapat tulisan-tulisan tentang rahib-rahib yang mengasingkan diri di padang pasir Arabia. Dikatakan bahwa zahid dan sufi Islam meninggalkan dunia, memilih hidup sederhana dan mengasingkan diri adalah pengaruh dari cara hidup rahibrahib Kristen ini.

2. Falsafat mistik Phytagoras yang berpendapat bahwa roh manusia bersifat kekal dan berada di dunia sebagai orang asing. Badan jasmani merupakan penjara bagi roh. Kesenangan roh yang sebenarnya ialah di alam samawi. Dan untuk memperoleh hidup senang di alam samawi, 
manusia harus membersihkan roh dengan meninggalkan hidup materi yaitu zuhud.

3. Falsafat emanasi Plotinus yang mengatakan bahwa wujud ini memancar dari zat Tuhan yang Maha Esa. Roh berasal dari Tuhan dan akan kembali kepada Tuhan. Dan untuk kembali, roh harus bersih kembali karena sudah kotor ketika memasuki alam materi. Penyucian roh tersebut dengan meninggalkan dunia dan mendekati Tuhan sedekat mungkin.

4. Ajaran Budha dengan paham nirwananya. Untuk mencapai nirwana, seseorang harus meninggalkan dunia dan memasuki hidup kontemplasi. Paham fana' dalam sufisme hampir sama dengan paham nirwana.

5. Ajaran-ajaran Hinduisme yang juga mendorong manusia untuk meninggalkan dunia dan mendekati Tuhan untuk mencapai persatuan Atman dengan Brahman

Menurut Ignaz Goldziher, asal usul tawasuf merupakan pengaruh dari unsur-unsur di luar Islam. Lanjutnya, tasawuf adalah salah satu warisan ajaran dari berbagai agama dan kepercayaan yang mendahului dan bersentuhan dengan Islam. Seperti ajaran tasawuf Islam yang memiliki beberapa persamaan dengan ajaran Budha. Menurutnya, Sidharta Gautama memiliki persamaan dengan Ibrahim bin Adam yang meninggalkan kemewahan sebagai putra mahkota. Selain itu, penggunaan tasbih, budaya etis, asketis serta abstraksi intelektual merupakan pinjaman dari Budhisme. ${ }^{18}$

Ada juga pendapat yang mengatakan bahwa ajaran tasawuf berasal dari Persia. Bahkan Thoulk, seorang orientalis dari abad ke19, menganggap bahwa tasawuf diambil dari sumber Majusi, dengan alasan bahwa sejumlah besar orang-orang Majusi di Iran Utara, setelah penaklukan Islam, tetap memeluk agama mereka, dan banyak tokoh sufi yang berasal dari sebelah utara kawasan Khurasan. Di samping kenyataan bahwa sebagian pendiri aliran-aliran sufi angkatan pertama berasal dari kelompok orang-orang Majusi.

Sementara orientalis seperti M. Horten dan R. Hartman berpendapat bahwa tasawuf berasal dari sumber India. Mereka cenderung merujuk kepada sebagian teori tasawuf, dan bentuk-bentuk tertentu dari latihan-latihan ruhaniah praktisnya, kepada praktikpraktik yang serupa dalam mistisisme orang-orang India. ${ }^{19}$

Sedangkan pendapat yang berbeda datang dari para tokoh sufi dan cendekiawan muslim. Dimana mereka memberikan pendapat bahwa sumber utama ajaran tasawuf adalah bersumber dari al-Qur'an dan Hadis. Dalam al-Qur'an banyak ditemukan sejumlah ayat yang 
berbicara tentang inti ajaran tasawuf seperti khauf, raja', taubat, zuhud, tawakkal, syukur, sabar, ridha, fana, mahabbah, dan lain sebagainya.

Hal tersebut juga ditemukan dalam hadis. Dimana juga banyak dijelaskan mengenai kehidupan rohaniah sebagaimana ditekuni oleh kaum sufi. Dua hadis yang diriwayatkan oleh Bukhari dan Muslim: "Sembahlah Allah seolah-olah engkau melihat-Nya, maka apabila engkau tidak melihat-Nya, maka Ia pasti melihatmu" dan hadis lain: "Siapa yang kenal pada dirinya, niscaya kenal dengan Tuhan-Nya" menjadi landasan kuat bahwa ajaran tasawuf bersumber dari ajaran Islam. ${ }^{20}$

Selanjutnya, Abu Nashr As-Siraj al-Thusi mengatakan, bahwa ajaran tasawuf pada dasarnya digali dari al-Qur'an dan as-Sunah, karena amalan para sahabat, menurutnya tentu saja tidak keluar dari ajaran al-Qur'an dan as-Sunnah. Demikian pula menurut Abu Nashr, bahwa para sufi dengan teori-teori mereka tentang akhlak pertamapertama sekali mendasarkan pandangan mereka kepada al-Qur'an dan as-Sunnah.

Selanjutnya di dalam kehidupan Nabi Muhammad SAW juga terdapat banyak petunjuk yang menggambarkan dirinya sebagai seorang sufi. Nabi Muhammad telah melakukan pengasingan diri ke Gua Hira menjelang datangnya wahyu. Dia menjauhi pola hidup kebendaan di mana waktu itu orang Arab menghalalkan segala cara untuk mendapatkan harta. Dikalangan para sahabat pun juga kemudian mengikuti pola hidup seperti yang dilakukan oleh Nabi Muhammad SAW. Abu bakar Ash-Shiddiq misalnya berkata: "Aku mendapatkan kemuliaan dalam ketakwaan, kefanaan dalam keagungan dan rendah hati'. Demikian pula sahabat-sahabat beliau lainnya seperti Umar bin Khattab, Utsman bin Affan, Ali bin Abi Thalib, Abu Dzar al-Ghiffari, Bilal, Salman al-Farisi dan Huzaifah alYamani. ${ }^{21}$

Menurut At-Taftazani, para sufi tidaklah sekadar menukil orang-orang Persia, Kristen, Yunani, atau lainnya, karena tasawuf pada dasarnya berkaitan dengan perasaan dan kesadaran. Jiwa manusia adalah satu, sekalipun terdapat perbeuaan bangsa atau rasnya. Apa pun yang berkaitan dengan jiwa manusia, lewat latihanlatihan ruhaniah, memang bisa saja sama, meskipun tidak terdapat kontak di antara keduanya. Ini berarti adanya benang merah di antara pengalaman para sufi, betapa pun berbedanya interpretasi antara seorang sufi yang satu dengan yang lainnya sesuai dengan beragamnya budaya di mana ia hidup. ${ }^{22}$ 


\section{Sejarah Perkembangan Tasawuf}

Tokoh pertama yang dijuluki "sufi" dalam sejarah Islam adalah seorang ahli zuhud bernama Abu Hasyim al-Kufi yang wafat di Baghdad pada tahun $150 \mathrm{H}$. Sehingga dapat dipastikan bahwsanya kata sufi baru digunakan pada abad kedua Hijriah atau setelah masa para sahabat Rasulullah dan tabi'in. ${ }^{23}$

Hal tersebut senada dengan pernyataan dari Imam Qusyairi dalam kitabnya Risalah Al-Qusyairiyah, bahwa tidak ada gelar yang lebih mulia dibandingkan dengan gelar sahabat, tabi'in dan tabi'i attabiin pada masanya masing-masing. ${ }^{24}$

Sejak dekade akhir abad II Hijriah, sufisme sudah popular di kalangan masyarakat di kawasan dunia Islam, sebagai perkembangan lanjutan dari gaya keberagaman para zahid dan 'abid, kesalehan yang mengelompok di serambi mesjid Madinah. Fase awal ini juga disebut sebagai fase asketisme yang merupakan bibit awal tumbuhnya sufisme dalam peradaban Islam. Keadaan ini ditandai oleh munculnya individu-individu yang lebih mengejar kehidupan akhirat, sehingga perhatiannya terpusat untuk beribadah dan mengabaikan keasyikan duniawi. Fase asketisme ini setidaknya berlangsung sampai akhir abad II Hijriah, dan memasuki abad ke III sudah menampakkan adanya peralihan dari asketisme ke sufisme. Fase ini dapat disebut sebagai fase kedua, yang ditandai oleh (antara lain) pergantian sebutan zahid menjadi sufi. Di sisi lain, pada kurun waktu ini percakapan para zahid sudah meningkat pada persoalan bagaimana jiwa yang bersih itu, apa itu moralitas dan bagaimana pembinaannya serta perbincangan masalah kerohanian lainnya. Tindak lanjut dari diskusi ini, bermunculanlah berbagai konsepsi tentang jenjang perjalanan yang harus ditempuh seorang sufi (almaqamat) serta ciri-ciri yang dimiliki oleh seorang salik (calon sufi) pada tingkatan tertentu (al-ahwal). Demikian juga pada periode ini sudah mulai berkembang perbincangan tentang pada derajat fana dan ittihad. Bersamaan dengan itu, tampillah para penulis tasawuf terkemuka, seperti al-Muhasibi (w.234 H), al-Harraj (w. 277H) dan al-Junaid al-Baghdadi (w. 297H), dan penulis lainnya. Secara konseptual-tekstual lahirnya sufisme barulah pada periode ini, sedangkan sebelumnya hanya berupa pengetahuan perorangan dan atau semacam langgam keberagamaan. Sejak kurun waktu itu sufisme berkembang terus ke arah penyempurnaan dan spesifikasi terminology seperti konsep intuisi, dzauq dan al-kasyf. 
Kepesatan perkembangan sufisme, nampaknya memperoleh dorongan setidaknya dari tiga faktor penting, yaitu: pertama adalah karena gaya kehidupan yang glamour-profanistik dan corak kehidupan materialis-konsumeris yang diperagakan oleh sebagian besar penguasa negeri yang segera menular di kalangan masyarakat luas. Dari aspek ini, dorongan yang paling kuat adalah sebagai reaksi terhadap gaya murni ethis, melalui pendalaman kehidupan rohaniahspiritual. Tokoh popular yang dapat mewakili kelompok ini dapat ditunjuk Hasan al-Bashri (w. 110H) yang mempunyai pengaruh kuat dalam kesejahteraan spiritual Islam, melalui doktrin al-zuhd, al-khauf dan al-raja'. Selain tokoh ini, juga Rabiah al-Adawiyah (w.185H) dengan ajaran populernya al-mahabbah serta Ma'ruf al-Kharki (w. $200 \mathrm{H}$ ) dengan konsepsi al-syauq sebagai ajarannya, juga adalah pelopor angkatan ini.

Kedua, timbulnya sikap apatis sebagai reaksi maksimal terhadap radikalisme kaum Khawarij dan polaritas politik yang ditimbulkannya. Kekerasan pergulatan kekuasaan pada masa itu, menyebabkan orang-orang yang ingin mempertahankan kesalehan dalam suasana kedamaian rohaniah dan keakraban cinta sesame, terpaksa memilih sikap menjauhi kehidupan masyarakat ramai dengan menyepi dan sekaligus menghindarkan diri dari keterlibatan langsung dengan pertentangan politik. Sikap yang demikian itu melahirkan ajaran 'uzlah dimana konseptornya adalah Surri alSaqathi (w. 253H). Apabila dilihat dari aspek sosiologi, nampaknya kelompok ini bisa dikategorikan sebagai gerakan sempalan, satu kelompok ummat yang sengaja mengambil sikap 'uzlah kolektif yang cenderung ekslusif dan kritis terhadap penguasa. Dilihat dari sisi motivasi ini, kecenderungan memilih kehidupan rohaniah mistis, sepertinya merupakan pelarian atau mencari kompensasi untuk memenangkan pertempuran ukhrawi di medan duniawi. Ketika di dunia yang sarat dengan tipu daya ini sudah kering dari siraman cinta kasih, mereka bangun dunia baru, realitas baru yang terbebas dari keserakahan dan kekejaman yakni dunia spiritual yang penuh dengan kecintaan dan kebijakan.

Ketiga, nampaknya adalah karena faktor kodifikasi hukum Islam (fiqh) dan perumusan ilmu kalam (teologi) yang dialektisrasional, sehingga kurang bermotivasi ethical yang menyebabkan kehilangan nilai spiritualnya menjadi semacam wahana tiada isi, semacam bentuk tanpa jiwa. Formalitas paham keagamaan dirasakan semakin mengeringkan dan menyesakkan ruh al-din yang berakibat terputusnya komunikasi langsung dan suasana keakraban personal 
antara hamba dan Khaliqnya. Kondisi hukum dan teologi yang kering tanpa jiwa itu, dihadapkan pada dominannya posisi moral dalam agama, menggugah para zuhud untuk mencurahkan perhatian terhadap moralitas, sehingga memacu pergeseran asketisme kesalehan kepada sufisme. Doktrin al-zuhud misalnya yang tadinya sebagai dorongan untuk meninggalkan ibadah semata-mata karena takut pada siksa neraka, bergeser kepada demi kecintaan dan sematamata karena Allah, agar selalu dapat berkomunikasi dengan-Nya. Konsep tawakkal yang tadinya berkonotasi kesalehan yang etis, kemudian secara diametral dihadapkan kepada pengingkaran kehidupan duniawi-profanistik di satu pihak dan konsep sentral tentang hubungan manusia dengan Tuhan, yang kemudian popular dengan doktrin al-hubb. Doktrin ini adalah semacam pra-ma'rifat yakni mengenal Allah secara langsung melalui pengalaman bathin. Menurut sebagian sufi (tasawuf sunni) ma'rifatullah adalah tujuan akhir dan merupakan tingkat kebahagiaan yang paripurna yang bisa dicapai manusia di dunia ini. Untuk bisa mencapai kualitas ilmu seperti itu, harus melalui proses inisiasi yang panjang dan bertingkattingkat dan hanya dimiliki orang-orang tertentu saja.

Dalam kurun waktu yang sama, tampil Dzu al-Nan al-Mishri (w.245H) dengan konsepsi metodologi spiritual menuju Allah, yakni al-maqamat yang secara parallel berjalan bersama hal-hal yang bersifat psiko-gnostik. Sejak diterima secara luas konsepsi almaqamat dan al-ahwal ini, perkembangan tasawuf telah sampai pada tingkat kejelasan perbedaannya dengan kesalehan asketis, baik dalam tujuan maupun ajarannya. Selain dari pada itu, sejak periode ini kelihatannya untuk menjadi seorang sufi semakin berat dan sulit, hampir sama halnya dengan kelahiran kembali seorang manusia, bahkan jauh lebih berat dari kelahiran pertama. Karena kalau kelahiran pertama menyongsong kehidupan duniawi yang mengasyikkan, tetapi pada kelahiran kedua ini, justru melepas dan membuang kehidupan material yang menyenangkan, untuk kembali kea lam rohaniyah, pengabdian dan kecintaan serta kesatuan dengan alam malakut. Sementara itu pada abad ketiga ini juga Abu Yazid alBusthami (w.260H) melangkah lebih maju dengan doktrin al-ittihad melalui al-fana, yakni beralih dan meleburnya sifat kemanusiaan (nasut) seseorang ke dalam sifat ilahiyah sehingga terjadi penyatuan manusia dengan Tuhan dalam al-fana.

Sejak munculnya doktrin al-fana dan al-ittihad, terjadi pulalah pergeseran tujuan akhir dari sufisme. Kalau mulanya sufisme bertujuan ethis, yakni agar selalu dengan Allah sehingga dapat berkomunikasi langsung dengan Allah, maka selanjutnya tujuan itu 
menaik lagi pada tingkat penyatuan diri dengan Tuhan. Konsep ini berangkat dari paradigma bahwa manusia yang secara biologis adalah jenis makhluk yang mampu melakukan satu transformasi dan transendensi melalui peluncuran ( $\left.m i{ }^{\prime} r a j\right)$ spiritual ke alam ketuhanan. Berbarengan dengan itu, timbul pula sikap pro-kontra terhadap konsep al-ittihad dan menjadi salah satu sumber terjadinya konflik dalam dunia pemikiran Islam, baik intern sufisme maupun dengan fuqaha dan para teolog. Dua kelompok ini secara bersama menuduh penganut sufisme al-ittihad sebagai gerakan sempalan yang telah merusak prinsip-prinsip Islam. Apabila dilihat dari sisi tasawuf sebagai ilmu, maka fase ini merupakan fase ketiga yang ditandai dengan mulainya unsur-unsur luar Islam yang berakulturasi dan bahkan sinkretis dengan sufisme. Masalah lain yang penting dicatat adalah bahwa pada kurun waktu ini juga timbul ketegangan antara kaum ortodoks Islam dan penganut sufisme awal (kesalehan asketis) di satu pihak dengan sufisme yang berpaham ittihad di pihak lain. ${ }^{25}$

Kaum sufi sendiri terbagi menjadi dua golongan utama yakni; pertama, para sufi yang berangkat dari keilmuan untuk menggapai sayap-sayap makrifat. Bagi golongan ini, segala yang mereka saksikan dalam bentuk siklus dan perubahan serta pembentukan di segenap entitas, memberi mereka ratusan pesan yang berasal dari hadrah Kekuasaan dan Kehendak Allah. Dan setiap kejadian selalu membisikkan berbagai bentuk senandung yang beragam dengan berbagai lisan yang berbeda-beda.

Sedangkan golongan kedua, para sufi yang menempuh jalan suluk hanya demi mencari rasa (dzauq), ekstase (wajd) dan penyingkapan (kasyf). Sehingga mereka mampu menghidupkan "kejauhan" di dalam wilayah "kedekatan", karena terkadang mereka melupakan tujuan, meski mereka selalu serius dalam menempuh perjalan, suluk dan kezuhudan. ${ }^{26}$

\section{E. Ajaran dan Pengamalan Tasawuf}

Menurut Asep Usman Ismail, ajaran dan pengamalan tasawuf terfokus pada tiga kegiatan (amaliah), sebagai berikut;

Pertama, tazkiyatun nafs, yakni membersihkan diri dari dosa besar maupun dosa kecil, serta membersihkan diri dari berbagai penyakit hati dan sifat-sifat tercela. Menurut As-Sarraj (w. 988 M), ada empat langkah utama yang biasa dilakukan oleh para sufi dalam hal tazkiyatun nafs. Keempat kegiatan tersebut adalah: 
1. Al-Ibadat, yakni melakukan berbagai ibadah secara konsisten dan berkesinambungan baik yang wajib maupun yang sunah.

2. Al-Mujahadat, yakni perjuangan untuk melawan berbagai dorongan nafsu dan bisikan setan.

3. Ar-Riyadat, yaitu melakukan latihan-latihan keruhanian berupa ibadah sunnah seperti puasa, shalat, dzikir, dan wirid secara teratur. Latihan-latihan ini juga harus diimbangi dengan latihan diri dari kebiasaan yang baik.

4. Al-Inqitha' ilallah, yakni menguatkan tekad dan arah bahwa hidup dan kehidupan ini semata-mata untuk Allah. Dengan kegiatan ini para sufi mengokohkan arahan pada diri mereka sendiri untuk membiasakan niat guna mencari keridhaan Allah sebelum memulai suatu pekerjaan.

Kedua, yakni taqarrub ilallah (mendekatkan diri kepada Allah dengan sedekat-dekatnya). Memberikan perhatian serius kepada usaha-usaha pengamalan tasawuf adalah perjuangan untuk menghampiri Allah yang diakui-Nya dekat dengan para hamba, bahkan lebih dekat daripada jarak manusia dengan urat lehernya.

Ketiga, hudhurul qalbi ma'a Allah, yakni merasakan kehadiran Allah di dalam kalbu. Amaliah ini memfokuskan diri pada perjuangan merasakan kehadiran Allah dan melihat-Nya dengan mata hati, bahkan hingga merasakan kesatuan diri dengan-Nya. Ketiga amaliah di atas harus selalu dibarengi dengan landasan akidah yang sesuai dengan syariat Islam. Sebab di dalam Islam tidak ada tasawuf yang berdiri sendiri, tanpa dipadukan dengan landasan akidah dan pengamalan syariat. ${ }^{27}$

\section{F. Maqamat}

قام - يقوم - قوماو قياما Secara bahasa, maqamat berasal dari fiil yang bermakna berdiri, bangkit atau berhenti. ${ }^{28}$ Akan tetapi, maqamat dalam kajian tasawuf bermakna tempat berhenti dalam sebuah perjalanan ruhani atau tangga dalam sebuah pendakian ruhani. Makna yang digunakan adalah makna konotatif bukan denotatif dari kata tersebut. $^{29}$

Abu Nasr As-Sarraj At-Tusi menjelaskan bahwa maqamat adalah kedudukan seorang hamba di hadapan Allah yang berhasil diperolehnya melalui ibadah, perjuangan melawan hawa nafsu, berbagai latihan spiritual dan penghadapan segenap jiwa raga kepada Allah swt. ${ }^{30}$ 
Disebutkan oleh Harun Nasution, bahwa tidak ada jumlah yang pasti mengenai maqamat ini. Misalnya Abu Bakr Muhammad al-Kalabadi yang menyebutkan 10 maqamat yakni tobat - zuhud sabar - kefakiran - tawadu' - takwa - tawakkal - ridha - cinta makrifat. Abu Hamid Al-Ghazali dalam Ihya' Ulum al-Din menyebutkan 8 maqamat sebagai berikut tobat - sabar - kefakiran zuhud - tawakal - cinta - makrifat - kerelaan.

Jalan yang harus dilalui seorang sufi tidaklah mudah. Jalan tersebut begitu sulit dilalui. Sehingga untuk berpindah dari satu maqam ke maqam selanjutnya membutuhkan usaha yang berat dan waktu yang lama. Maka tidak mengherankan apabila seorang calon sufi harus bertahun-tahun tinggal dalam satu maqam. ${ }^{31}$

\section{G. Kesimpulan}

Tasawuf merupakan salah satu ajaran Islam dalam proses mendekatkan diri kepada Allah dengan melalui proses-prosesnya. Proses tersebut tidaklah mudah sehingga menuntut usaha ekstra keras dari pelakunya.

Berkaitan dengan makna tasawuf sendiri banyak terdapat perbedaan pendapat, terutama jika ditinjau dari segi bahasa atau etimologi. Ada yang mengatakan bahwa asal kata tasawuf adalah $a h l$ ash-shuffah, atau dari kata suf (kain wol kasar). Bahkan ada yang sampai menghubungkannya dengan bahasa Yunani, sophos. Dan beberapa pendapat lainnya. Akan tetapi pendapat yang banyak diterima adalah berasal dari kata suf karena kesederhanaan kaum sufi.

Begitu pula, masing-masing ulama memiliki definisi terkait tasawuf. Di antara banyaknya definisi, ada dua hal utama yang menjadi dasar makna tasawuf yakni kesucian jiwa untuk menghadap Allah dan mendekatkan diri secara individu kepada-Nya.

Perjalanan yang dilakukan oleh salik (calon sufi) melalui beberapa maqamat. Yakni taubat, zuhud, sabar, tawakal, ridha, cinta dan makrifat. Dan taubat merupakan pondasi awal guna mencapai tingkatan sufi. Oleh karena itu, taubat merupakan maqamat paling penting.

${ }^{1}$ Harun Nasution, Falsafat dan Mistisme dalam Islam, (Jakarta: PT Bulan Bintang, 2002), h. 43. 
2 Terdapat banyak pendapat tentang definisi dari Ahl al-șuffah. Berdasarkan pengertiannya, menurut Abu al-A'la al-Afify, sebagaimana dikutip oleh Muhammad Hafiun, mengatakan bahwa Ahl al-ṣuffah adalah nama yang diberikan kepada sebagian fakir miskin di kalangan orang Islam pada masa awal Islam. Mereka adalah di antara orang-orang yang tidak punya rumah, maka menempati gubuk yang telah dibangun Rasulullah di luar masjid di Madinah. Lihat Muhammad Hafiun, "Teori Asal Usul Tasawuf”, Jurnal Dakwah, Vol. XIII, No. 2 (2012), h. 242; Pendapat lain mengatakan bahwa Ahl al-șuffah adalah mereka yang melayani Ka'bah dengan tekun beribadah. Sebagaimana pendapat Ar-Raghib AlAshfahani, Mufradat alfaz al-Qur'an, (Damaskus: Dar al-Qalam, 2009), h. 499.

${ }^{3}$ Pendapat ini serupa dengan yang dikemukakan oleh sufi muslim, Abdul Wahid Yahya. Ia mengatakan bahwasanya penamaan ini mengisyaratkan pada makna al-hikmah al-ilahiyyah, hikmah ketuhanan. Lihat Jamal Sa'd Mahmud Jum'ah, Fi Riyadh al-Tasawwuf al-Islami, Cetakan Pertama, (Kairo: t.p, 2002). h, 26.

${ }^{4}$ Pendapat ini sebagaimana disampaikan oleh al-Biruni. Lihat Jamal Sa'd Mahmud Jum'ah, Fi Riyadh al-Tasawwuf al-Islami,h. 25.

5 Ada satu riwayat tentang ucapan Hasan Al-Bashri yang menyatakan bahwa ia menemukan bahwasanya 70 sahabat yang mengikuti perang Badar menggunakan pakaian berbahan wol. Lihat As-Sahrawardi, Awarif al-Ma'arif, (Kairo: Maktabah Ats-Tsaqafah Ad-Diniyyah, 2006), h. 70.

${ }^{6}$ Lihat Asep Usman Ismail, Tasawuf Menjawab Tantangan Global, (Jakarta: Transpustaka, 2012), h. 66-70; Keterangan serupa juga ditemukan dalam buku Harun Nasution, Falsafat dan Mistisme dalam Islam, h. 43-44. Hanya saja, Harun tidak menyebutkan point keenam dalam bukunya tersebut; Selain itu, AlRaghib Al-Aṣfahani juga menyebutkan bahwa kata صوفي juga mengandung beberapa makna. Pertama, bisa dimaknai dengan pakaian berbahan wol. Kedua, dinisbatkan kepada ahl ash-shüfah, yakni sebuah kaum yang menyibukkan dirinya untuk beribadah kepada Allah. Dan ketiga, disandarkan kepada الصوفان yakni sejenis buah-buahan yang berbentuk kecil dan berbulu. Lihat Ar-Raghib AlAshfahani, Mufradat alfaz al-Qur'an, h. 499.

7 Pendapat ini dikutip dari Ibnu 'Ajibah. Lihat Abdul Qadir Isa alHusainy, haqaiq an at-tashawwuf.

${ }^{8}$ Jamal Sa'd Mahmud Jum'ah, Fi Riyadh al-Tasawwuf al-Islami,h. 19.

${ }^{9}$ Ibnu Manẓūr, Lisān al- 'Arab, Jilid 4 (Kairo: Dār al-Ma‘ārif, 1119), h. 2527.

${ }^{10}$ Muhammad Fu'ād 'Abdul Bāqī, Al-Mu'jam al-Mufahrass li Alfāz alQur'ān al-Karìm (T.tp.: Dārul Kutub al-Mișriyyah, 1346 H), h. 417.

${ }_{11}$ Abu Abdillah Muhammad bin Umar bin al-Hasan bin al-Husain AlTaymiy al-Razi, Mafatih al-Ghaib, Jilid 9, h. 443. Fakhruddin Ar-Razi dalam kitabnya ini menggunakan redaksi adh-dha'n (الضأن) yang bermakna domba atau biri-biri; sedangkan Al-Samarqandi menggunakan redaksi al-ghanam (الغنم) biasanya lafaz ini digunakan untuk menunjukkan hewan kambing. Tapi juga bisa dimaknai dengan domba atau biri-biri. Lihat Al-Samarqandi, Bahr al-Ulum, Jilid 2, h. 477.

12 Syamsun Ni'am, Tasawuf Studies: Pengantar Belajar Tasawuf, (Yogyakarta: Ar-Ruzz Media, 2014), h. 28-29.

${ }^{13}$ Muhammad Hafiun, “Teori Asal Usul Tasawuf”, h. 244. 
${ }^{14}$ Syamsun Ni'am, Tasawuf Studies: Pengantar Belajar Tasawuf, h. 2930.

${ }^{15}$ Asep Usman Ismail, Tasawuf Menjawab Tantangan Global, h. 70.

${ }^{16}$ Muhammad Hafiun, "Teori Asal Usul Tasawuf”, h. 245.

${ }^{17}$ Harun Nasution, Falsafat dan Mistisme dalam Islam, h. 44-45.

${ }^{18}$ Muhammad Hafiun, “Teori Asal Usul Tasawuf”, h. 247-249.

${ }^{19}$ Syamsun Ni'am, Tasawuf Studies: Pengantar Belajar Tasawuf, h. 5556.

${ }^{20}$ Muhammad Hafiun, “Teori Asal Usul Tasawuf”, h. 246.

${ }^{21}$ Muhammad Hafiun, “Teori Asal Usul Tasawuf”, h. 247.

${ }^{22}$ Syamsun Ni'am, Tasawuf Studies: Pengantar Belajar Tasawuf, h. 60.

${ }^{23}$ Muhammad Fathullah Gulen, Tasawuf Untuk Kita Semua, (Jakarta: Republika, 2013), h. 19.

${ }^{24}$ Muhammad Fathullah Gulen, Tasawuf Untuk Kita Semua, h. 20.

${ }^{25}$ Zuherni AB, "Sejarah Perkembangan Tasawuf", Jurnal Substantia, Vol.

13, No. 2 (Oktober 2011), h. 250-252.

${ }^{26}$ Muhammad Fathullah Gulen, Tasawuf Untuk Kita Seтua, h. 22-23.

${ }^{27}$ Asep Usman Ismail, Tasawuf Menjawab Tantangan Global, h. 73-77.

28 Ahmad Warson Munawwir, Al-Munawwir Kamus Arab-Indonesia (Surabaya: Pustaka Progressif, 1997), h. 1172.

${ }^{29}$ Asep Usman Ismail, Tasawuf Menjawab Tantangan Global, h. 77.

${ }^{30}$ Asep Usman Ismail, Tasawuf Menjawab Tantangan Global, h. 80-81.

${ }^{31}$ Harun Nasution, Falsafat dan Mistisme dalam Islam, h. 48-49.

\section{DAFTAR PUSTAKA}

AB, Zuherni. "Sejarah Perkembangan Tasawuf", Jurnal Substantia, Vol. 13, No. 2 (Oktober 2011), h. 249-256.

Al-Ashfahani, Ar-Raghib. 2009. Mufradat alfaz al-Qur'an, Damaskus: Dar al-Qalam.

Al-Husainy, Abdul Qadir Isa. haqaiq an at-tashawwuf.

Al-Razi, Abu Abdillah Muhammad bin Umar bin al-Hasan bin alHusain Al-Taymiy, Mafatih al-Ghaib, Jilid 9.

Al-Samarqandi, Bahr al-Ulum, Jilid 2,

As-Sahrawardi, 2006, Awarif al-Ma'arif, Kairo: Maktabah AtsTsaqafah Ad-Diniyyah.

Bāqī, Muhammad Fu'ād 'Abdul. 1346 H. Al-Mu'jam al-Mufahrass li Alfāz al-Qur'ān al-Karīm, T.tp.: Dārul Kutub al-Mișriyyah.

Gulen, Muhammad Fathullah. 2013, Tasawuf Untuk Kita Semua, Jakarta: Republika. 
Hafiun, Muhammad. "Teori Asal Usul Tasawuf", Jurnal Dakwah, Vol. XIII, No. 2 (2012), h. 241-253.

Ismail, Asep Usman. 2012. Tasawuf Menjawab Tantangan Global, Jakarta: Transpustaka.

Jum'ah, Jamal Sa'd Mahmud. Fi Riyadh al-Tasawwuf al-Islami, Cetakan Pertama, (Kairo: t.p, 2002)

Manz̄ūr, Ibnu. 1119, Lisān al- 'Arab, Jilid 4, Kairo: Dār al-Ma'ārif.

Munawwir, Ahmad Warson. 1997. Al-Munawwir Kamus ArabIndonesia, Surabaya: Pustaka Progressif.

Nasution, Harun. 2002. Falsafat dan Mistisme dalam Islam, Jakarta: PT Bulan Bintang.

Ni'am, Syamsun. Tasawuf Studies: Pengantar Belajar Tasawuf, Yogyakarta: Ar-Ruzz Media. 